\title{
HIV epidemic among men who have sex with men in the Czech Republic, 2016: high time for targeted action
}

Viktor Mravčík ${ }^{1,2,3}$, Michal Pitoňák3, Robert Hejzák4, Barbara Janíková1,2, Ivo Procházka ${ }^{5}$

1. National Monitoring Centre for Drugs and Addiction, Office of the Government of the Czech Republic, Prague, Czech Republic

2. Department of Addictology, First Faculty of Medicine, Charles University and General Teaching Hospital, Prague, Czech Republic

3. National Institute of Mental Health, Klecany, Czech Republic

4. Czech AIDS Help Society, Prague, Czech Republic

5. Institute of Sexology, First Faculty of Medicine, Charles University, Prague, Czech Republic

Correspondence: Viktor Mravčík (mravcik.viktor@vlada.cz)

Citation style for this article:

Mravčík Viktor, Pitoňák Michal, Hejzák Robert, Janíková Barbara, Procházka Ivo. HIV epidemic among men who have sex with men in the Czech Republic, 2016: high time for targeted action. Euro Surveill. 2017;22(48):pii=17-00079. https://doi.org/10.2807/1560-7917.ES.2017.22.48.17-00079

Reported incidence of human immunodeficiency virus (HIV) infection in the Czech Republic increased steeply over the past decade from 90 new cases in 2005 to 266 in 2015. This increase is almost exclusively attributed to sexual transmissions between men who have sex with men (MSM). In 2015, there were $79 \%(n=210)$ newly diagnosed cases among MSM, $17 \%(n=45)$ were attributed to heterosexual transmission and $1 \%(n=3)$ to people who inject drugs. Interventions targeted at MSM have not yet been prioritised in the broadly focused national HIV prevention strategy which this is envisaged to change in the programme set out for 2018 to 2022. The national budget for HIV prevention has been reduced, however, and this remains. Availability of voluntary counselling and testing has decreased substantially in the past decade. Post- and pre-exposure prophylaxis for sexual intercourse among MSM are not part of the HIV prevention policy and the concept of treatment as prevention is not fully recognised. Provision of a combined prevention strategy with a focus on MSM, reflecting the above factors including stigmatisation, should contribute to reverse the development of a concentrated HIV epidemic among MSM in the Czech Republic.

\section{Introduction}

Infection caused by human immunodeficiency virus (HIV) remains substantial public health concern worldwide associated with high mortality and morbidity, low quality of life, reduced life expectancy and high treatment costs, affecting certain vulnerable communities and subpopulations disproportionately [1].

Despite public health measures, significant HIV transmission continues in Europe. In 2015, 153,407 people were newly diagnosed with HIV in the World Health Organization (WHO) European Region (98,177 of them in Russia), which corresponds to 17.6 newly diagnosed infections per 100,000 of population (7.6 without Russia). In European Union and European Economic Area (EU/EEA) countries, the number of newly diagnosed infections reached 6.3 per 100,000 population; the lowest rate (2.3 per 100,000 population) was reported from central Europe. Sex between men was the most frequent route of transmission in the EU/EEA $(42.2 \%)$, while the proportion of people who inject drugs (PWID) was small (4.2\%). Whereas heterosexual and PWID transmission decreased over the last decade in the majority of EU/EEA countries, the number of newly reported HIV infections among men who have sex with men (MSM) has continuously increased [2].

\section{Situation in the Czech Republic}

The Czech Republic with its 266 newly-diagnosed HIV cases in 2015 (2.5 per 100,000 population) ranks, together with Slovakia and Slovenia, among the EU/ EEA countries with the lowest reported incidence. At the same time, the Czech Republic, together with Croatia, Hungary and Slovenia, is one of the EU/EEA countries with the highest proportion of MSM among newly-diagnosed cases (approx. 80\% and over) in the region [2].

In the past decade, the number of newly diagnosed HIV infections has been growing rapidly from 90 cases in 2005 to 266 cases annually in 2015. The increase has been attributed exclusively to sexual transmission between men; other modes of transmission have shown stable (PWID) or slightly increasing (heterosexual transmission) rates (Figure 1). In 2015, there were 210 (79\%) newly diagnosed cases among MSM, 45 cases $(17 \%)$ were attributed to heterosexual transmission and three cases ( $1 \%$ ) to PWID. More than half of the newly diagnosed cases (51\% in 2015) lived in the capital city, Prague [3], while in the general population, Prague inhabitants represent $12 \%$ of the population 


\section{FIGURE 1}

Annual number of newly diagnosed HIV infections among Czech citizens and residents, by transmission category, Czech Republic, 1985-2015

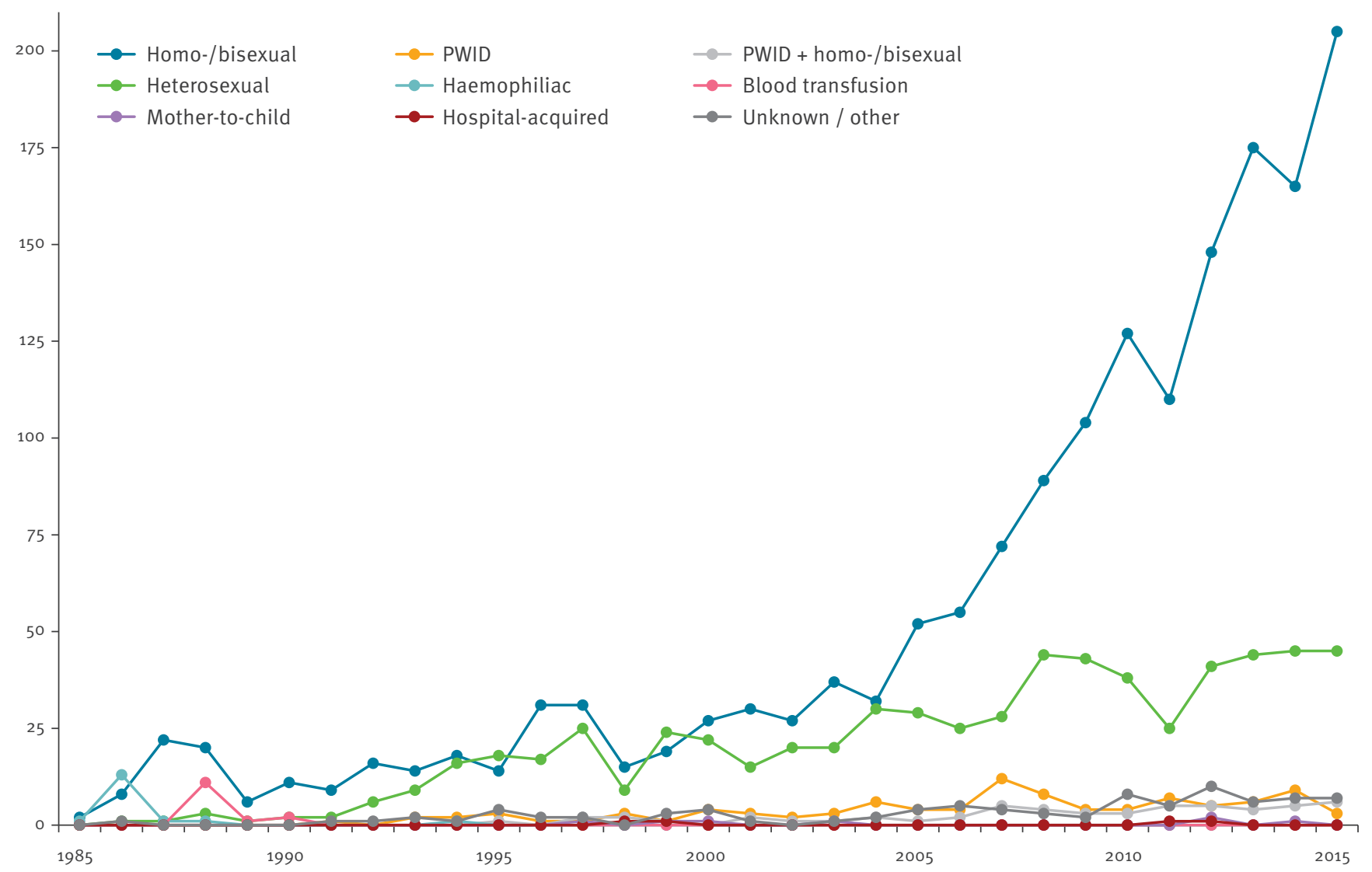

HIV: human immunodeficiency virus; PWID: people who inject drugs.

Source of the data: Malý et al. [3].

of the Czech Republic. Of 266 newly diagnosed HIV infections in 2015, 46 (17\%) cases were diagnosed late (acquired immunodeficiency syndrome (AIDS) or symptomatic non-AIDS stage) and $85 / 237$ (36\%) had $\mathrm{CD}_{4}{ }^{+} \mathrm{T}$-cell counts $<350 / \mathrm{mL}$ at diagnosis [3].

In a bio-behavioural survey among MSM carried out in six European cities (Barcelona, Bratislava, Bucharest, Ljubljana, Prague and Verona) in 2008 and 2009 as part of the Sialon project (the project for capacity building in HIV/syphilis prevalence estimation using noninvasive methods among MSM in southern and eastern Europe), HIV testing was performed among 400 MSM in Prague and resulted in a seroprevalence rate of $2.6 \%$, which was the lowest among the participating cities [4]. However, this rate does not necessarily account for the dynamics of the HIV epidemic in the Czech Republic in recent years. Up to the end of 2016, the cumulative number of newly-diagnosed HIV infections among MSM reached nearly 2,000 cases $[3,5]$, with at least 1,000 of them resident in Prague. In addition, many younger homo- or bisexual people are registered at the permanent address of their parents, but in fact they live, work or study in Prague. After we included undiagnosed cases, based on a rather conservative estimate of $30 \%$ latency (Němeček and Malý estimated up to $47 \%$ undiagnosed HIV cases in the Czech Republic in 2014 [6]; recent data for the EU/EEA estimated $17 \%$, however, the estimate for the Czech Republic is not available [7]), a total of 1,500 HIV-positive MSM were estimated in Prague. Applying results from a study in England [8], we estimate that at least $5 \%$ of Prague's male population are MSM and thus, at least 26,000 MSM aged 15 years and oldercan be assumed to live in Prague, of whom 1,500 are HIV-positive. This would correspond to an HIV seroprevalence of more than $5 \%$ among MSM in Prague, which is according to the WHO a threshold for a concentrated HIV epidemic.

Little is known about behavioural factors contributing to recent HIV transmission among MSM in the Czech Republic because research in this field is lacking. Data from the Sialon project showed lower condom use among Czech MSM during sexual intercourse with steady and especially with casual partners, compared with MSM from other participating countries; only $\mathbf{2 9 . 0 \%}$ of the Czech MSM used condoms in the last anal intercourse with a male partner [4]. The latest European 


\section{FIGURE 2}

Annual budget of the grant system of the National programme for tackling HIV/AIDS and newly diagnosed HIV infections in the Czech Republic in 2005-2015

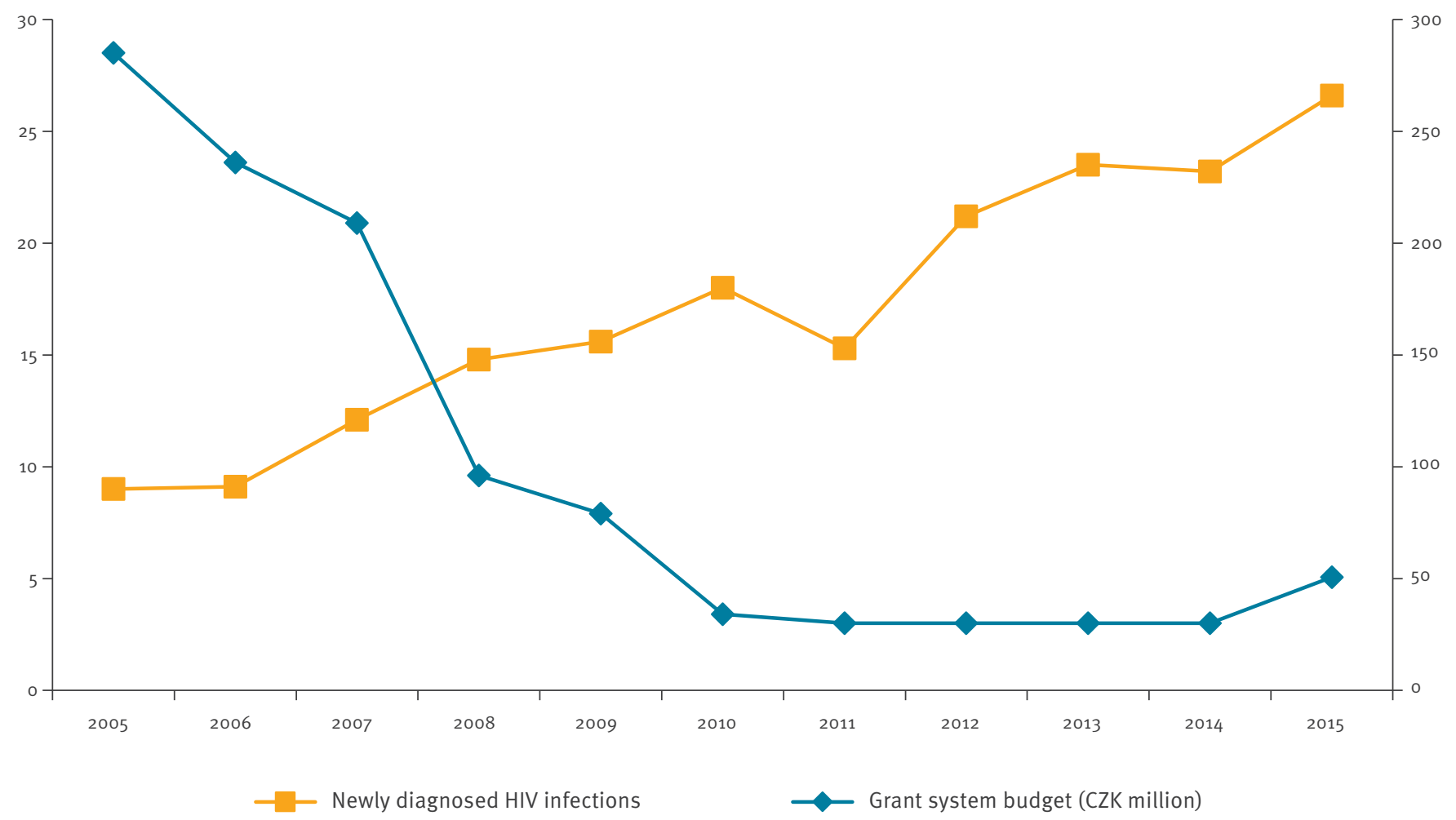

AIDS: acquired immunodeficiency syndrome; HIV: human immunodeficiency virus.

The exchange rate was approximately CZK 30 for EUR 1 in 2005 and CZK 27 for EUR 1 in 2015.

MSM Internet Survey (EMIS) data returned higher rates of condom use among Czech MSM (41.0\% during the last anal intercourse), however, this rate was lower than in other European countries. Nevertheless, the rate of unprotected anal intercourse with casual partners in the last 12 months (35.8\%) was comparable with the EU median (39.8\%), and casual sex as such in the last 12 months was less frequently reported in the Czech Republic (63.2\%, the lowest rate in EU) than in the $\operatorname{EU}(75.1 \%)[9]$.

According to the only available online survey that focused on chemsex primarily among MSM in the Czech Republic in 2016 ( $n=948$, among them 710 reported gay, 143 bisexual and 11 lesbian sexual orientation), methamphetamine was used during sexual activities by $14 \%$, ecstasy by $12 \%$, gamma-hydroxybutyric acid (GHB)/gamma-butyrolactone (GBL) by $8 \%$, mephedrone by $3 \%$ and other drugs (likely alcohol, cannabis or poppers) by $15 \%$ of respondents in the last 12 months (data not shown). Recent use of drugs characteristic for chemsex has been found much less prevalent among MSM in Prague than for example in London, Amsterdam or Paris, but comparable with many other metropolitan cities in Europe [10].
In addition to behavioral factors, further we discuss important structural factors moderating recent HIV epidemic among MSM in the Czech Republic.

\section{HIV/AIDS prevention policy and its funding}

Nowadays, so-called combination prevention, consisting of individual interventions such as testing, including community-based testing, with rapid tests and self-testing, behavioural risk reduction, condom distribution, needle and syringe programmes, treatment of other sexually transmitted infections (STI), and antiretroviral medications in treatment and preventive contexts, is recommended at the national and local levels, with sufficient scale, combination of interventions and coverage of the most-affected population groups including MSM [11].

The basic strategy document in the field of HIV/AIDS in the Czech Republic is the National programme for tackling HIV/AIDS in the period from 2013 to 2017 [12]. Although sex between men is the main transmission route and MSM are the most affected at-risk group in the Czech Republic, neither the MSM group nor activities targeting sex between men are defined as priorities and there is no single specific activity focusing on 
MSM in the programme. For example, the MSM group is listed without any emphasis as one among the 18 target groups of the programme. The next HIV/AIDS national programme for the period from 2018 to 2022, which is now being drafted, is expected to explicitly prioritise activities targeting MSM.

The main financial mechanism for HIV prevention in the Czech Republic is the grant system of the Ministry of Health for the National programme for tackling HIV/ AIDS, which is launched every year. As the grant programme runs on an annual basis, it might be a flexible tool for adjusting the policy priorities according to the actual situation, however, the same terms of reference for the grant call have been maintained over the last decade with no emphasis on addressing the main transmission route of the HIV epidemic - sex between men [13].

In contrast to the increasing number of newly diagnosed HIV infections, the prevention budget for the grant system of the National programme for tackling HIV/AIDS has been rapidly decreasing in the past decade. While in 2005, the budget was CZK 28.5 million (ca EUR 950,000), it was reduced in 2015 to CZK 5.1 million (ca EUR 190,000) (Figure 2). Although this HIV prevention budget could already be viewed as modest in 2005, it was indeed insufficient in 2015 even though since the beginning of the new millennium, the antiretroviral therapy (ART) treatment, which is available in eight regional HIV/AIDS treatment centres in the Czech Republic, has been covered by the public health insurance and is not included in the HIV prevention budget anymore. It shall be noted that volunteer work in HIV/ AIDS prevention is not common in the Czech Republic and involvement of target groups' peers and volunteers is therefore limited. In comparison, the harm reduction services for PWID, financed from the budget on drug policy, are supported with CZK 200 million annually (ca EUR 7.5 million), which is approximately 40 times more [14].

The competition for resources is tough between various state and non-governmental organisations in the field of HIV prevention, and in the absence of programmatic prioritisation, activities focused on MSM are not preferentially supported. Analysis of the titles of the projects supported in 2016 showed that among 37 projects financed with CZK 9.8 million in total, only eight projects with a summary budget of CZK 3 million (31\%) focused specifically on provision of testing, condoms, outreach work or social assistance to MSM [15].

The policy development in the area of HIV has to be seen in the context of overall public health policy. The public health service (consisting of public health authorities and public health institutes) underwent negative development in the period 2006 to 2012, leading to a substantial reduction of its capacity (e.g. $43 \%$ reduction of personnel capacity) especially in the fields of public health protection, health monitoring or health promotion [16]. This reduction concerned also the network of HIV/AIDS counselling centres operated within the public health service: while there were 54 of these centres run by the public health service in 2006 with broad national coverage, there were 23 centres in 2014, of which only 13 were run by the public health service. Consequently, the access to voluntary (anonymous) counselling and testing (VCT) decreased substantially [16], even though the voluntary testing and the testing of contacts of HIV-positive cases show the highest proportions of case detection, $0.7 \%$ and $4.3 \%$, respectively [3]. Availability and accessibility of VCT for MSM is crucial for early detection of HIV infection, especially when analysis of $\mathrm{CD}_{4}{ }^{+} \mathrm{T}$ cells at diagnosis shows that MSM have the lowest proportion of late diagnoses among all transmission groups in EU; this demonstrates higher testing rates and awareness in the MSM community compared with other at-risk populations [2].

\section{Prophylactic use of antiretroviral medications}

Besides post-exposure prophylaxis (PEP), antiretroviral medications have recently been recommended for pre-exposure prophylaxis (PrEP). PrEP is recommended especially in HIV-negative MSM and transgender individuals at high risk of HIV acquisition [17]. Continuous and on-demand PrEP has demonstrated high efficacy in preventing HIV seroconversion among MSM: it was well tolerated, the evolution of HIV resistance was low, while compensatory increased sexual risk behaviour was not observed [18]. PrEP as a standard modality or within demonstration projects is available or planned in 20 European countries, however, the Czech Republic is not among them [19]. Although some evidence suggests caution with respect to increased risk of other STIs among MSM on PrEP, implementation of PrEP can also be viewed as an opportunity for better STI detection and treatment among the most at-risk MSM [20]. However, use of PrEP by individuals infected with HIV but unaware of their infection can lead to the generation and further transmission of resistant viruses [21].

The Czech clinical guidelines for HIV contain a defined algorithm for PEP [22]. In an EMIS survey from 2010 [8], experience with PEP was reported by $0.4 \%$ of the MSM in the Czech Republic, which was among the lowest proportions of the countries participating in the survey. However, PrEP is not mentioned in the Czech clinical guidelines and as such is not formally available [22]. There are no data on informal use of PrEP in the Czech Republic, however, there are anecdotal reports from VCT centres on PrEP use among MSM.

Early initiation of treatment leads to viral supression and decreases or eliminates HIV transmision to sexual partners (treatment as prevention, TasP). Regarding ART initiation, the recent clinical guidelines, in place since 2016, recommend start of treatment with $\mathrm{CD}_{4}^{+} \mathrm{T}$ cell counts $>500 / \mathrm{mL}$ also in asymptomatic infections [22]. The previous version of the clinical guidelines 
adopted in 2012 recommended start at threshold $\mathrm{CD}_{4}{ }^{+} \mathrm{T}$ cells $<350 / \mathrm{mL}$ or $\mathrm{CD}_{4}{ }^{+} \mathrm{T}$ cells $=350-500 / \mathrm{mL}$ if other factors (such as dramatic $\mathrm{CD}_{4}^{+} \mathrm{T}$ cell decrease, high viral load, co-infections, other comorbidities, sex with a steady HIV-negative partner or pregnancy) were present; a threshold of $\mathrm{CD}_{4}^{+} \mathrm{T}$ cells $>500 / \mathrm{mL}$ was previously recommended only 'in special circumstances' [23]. Recent data on continuum of care indicate that $71 \%$ of those with diagnosed HIV infection receive ART, and $85 \%$ of them have viral suppression [6].

\section{Stigma affecting MSM}

Structural stigma refers to societal conditions, norms or policies that compromise the opportunities, resources and well-being of a socially marginalised group such as sexual minorities [24]. A growing body of research demonstrates that structural stigma in particular serves as a key driver of poor health outcomes among sexual minorities [25]. HIV infection in MSM represents double stigma on a personal and a community level associated with social exclusion, discrimination, rejection and violence [26].

In the Czech Republic, prejudice related to sexual minorities has been documented [27]. Also sex between men has been framed mostly negatively in some of the Czech mainstream media. Qualitative analysis of Czech media reports about HIV/AIDS showed that HIV transmission was often presented as a 'punishment for an abnormal behaviour such as injecting drug use or homosexual orientation' [28].

In 2016, stigmatisation of HIV-positive MSM in the Czech Republic has become a topic of public discussion in the aftermath of the prosecution of 30 HIV-positive homosexual men, most of them on ART treatment, who allegedly violated the Criminal Code for spreading infectious human disease practicing condomless sex $[29,30]$. Criminalisation for the reckless transmission of HIV is an intrinsic part of the structural stigma and remains controversial since HIV risk can increase with criminalisation as it reinforces stigma and fear of HIVpositive people and undermines HIV prevention efforts [31-34].

\section{Conclusions and recommendations}

MSM represent the group most at risk of HIV infection in the Czech Republic. The number of newly diagnosed HIV infections among MSM has grown rapidly in recent years and is currently reaching the level of a concentrated epidemic, especially in the capital city, Prague.

However, in the authors' opinion, the current epidemiological situation is not reflected in national policy development. Neither the core strategic and programmatic documents nor the financial support in the field of HIV/AIDS prevention prioritise activities focusing on MSM. Despite the current state of the HIV epidemic, HIV/AIDS prevention is underfinanced and is not focussed on specific activities targeting MSM such as outreach programmes, strategy for destigmatisation, condom distribution, community testing and early identification of possible contacts, or social support. PrEP has not been implemented or piloted so far and PrEP or TasP are not yet fully recognised by public health authorities or clinicians [35]. In addition, prejudice and stigma, together with other societal and structural factors, influences the disproportionate incidence of HIV in MSM.

Finally, we underline the importance of evidence-based formulation of priorities in prevention strategy and its funding schemes in order to achieve better provision of an HIV/AIDS integrated prevention strategy including PrEP, recognition of TasP and destigmatising HIV/AIDS and MSM.

\section{Acknowledgements}

Institutional support was provided by Charles University, PROGRES Programme No. Q06/LF1 and by the Project No. L01611 with a financial support from the Czech Ministry of Youth and Sport under the NPU I programme. This paper was supported by the joint action '677085 / HA-REACT' which has received funding from the European Union's Health Programme (2014-2020).

\section{Conflict of interest}

None declared.

Authors' contributions

VM: drafted concept of the paper. All authors: contributed to the content.

References

1. World Health Organization (WHO). Global health sector strategy on HIV 2016-2021. Geneva: WHO; 2016. Available from: http://www.who.int/hiv/strategy2016-2021/ghss-hiv/en/

2. European Centre for Disease Prevention and Control (ECDC)/ World Health Organization Regional Office for Europe. HIV/ AIDS surveillance in Europe 2015. Stockholm: ECDC; 2016. Available from: https://ecdc.europa.eu/sites/portal/files/ media/en/publications/Publications/HIV-AIDS-surveillanceEurope-2015.pdf

3. Malý M, Němeček V, Zákoucká H. Výskyt a šíření HIV/AIDS v České republice v roce 2015. [The prevalence and spread of HIV/AIDS in the Czech Republic in 2015]. Zprávy CEM. [Reports CEM]. 2016;25(9-10):320-30. Czech. Available from: http://www.szu.cz/uploads/documents/CeM/HIV_AIDS/ rocni_zpravy/2015/Vyrocni_zprava_0_vyskytu_a_sireni_HIV_ AIDS_v_CR_v_roce_2015.pdf

4. Mirandola M, Folch Toda C, Krampac I, Nita I, Stanekova D, Stehlikova D, et al. HIV bio-behavioural survey among men who have sex with men in Barcelona, Bratislava, Bucharest, Ljubljana, Prague and Verona, 2008-2009. Euro Surveill. 2009;14(48):19427. https://doi.org/10.2807/ese.14.48.19427en PMID: 20003897

5. Malý M, Němeček V, Zákoucká H. Tisková zpráva Národní referenční laboratoř̀e pro HIV/AIDS: Trendy vývoje a výskyt HIV/AIDS $\vee$ ČR $v$ roce 2016. [Press release of the national reference laboratory for HIV/AIDS: Trend and current situation in HIV/AIDS in the Czech Republic in 2016]. Prague: National Institute of Public Health; 2017. Czech. Available from: http://www.szu.cz/tema/prevence/ tiskova-zprava-nrl-pro-hiv-aids-trendy-vyvoje-a-vyskyt-hiv

6. Němeček V, Malý M. Diagnostika a epidemiologie HIV. Základy HIV poradenství, dne 11.12. 2014. [Diagnostics and epidemiology of HIV. Basics of HIV couselling, 11 December 2014]. Prague: National Institute of Public Health; 2014. Czech. 
7. European Centre for Disease Prevention and Control (ECDC). Continuum of HIV care. Monitoring implementation of the Dublin Declaration on Partnership to Fight HIV/AIDS in Europe and Central Asia: 2017 progress report. Stockholm: ECDC; 2017. Available from: https://ecdc.europa.eu/sites/portal/ files/documents/Continuum-of-HIV-care-2017.pdf

8. Hayes J, Chakraborty AT, McManus S, Bebbington P, Brugha $\mathrm{T}$, Nicholson S, et al. Prevalence of same-sex behavior and orientation in England: results from a national survey. Arch Sex Behav. 2012;41(3):631-9. https://doi.org/10.1007/s10508-0119856-8 PMID: 21975923

9. The EMIS network. EMIS 2010: The European men-who-havesex-with-men internet survey. Findings from 38 countries. Stockholm: European Centre for Disease Prevention and Control; 2013. Available from: https://ecdc.europa.eu/sites/ portal/files/media/en/publications/Publications/EMIS-2010european-men-who-have-sex-with-men-survey.pdf

10. Schmidt AJ, Bourne A, Weatherburn P, Reid D, Marcus U, Hickson FEMIS Network. Illicit drug use among gay and bisexual men in 44 cities: Findings from the European MSM Internet Survey (EMIS). Int J Drug Policy. 2016;38:4-12. https:// doi.org/10.1016/j.drugpo.2016.09.007 PMID: 27788450

11. Joint United Nations Programme on HIV/AIDS (UNAIDS). Fast-tracking combination prevention. Towards reducing new HV infections to fewer than 500000 by 2020. Geneva: UNAIDS; 2015. Available from: http://www.unaids.org/sites/ default/files/media_asset/20151019_JC2766_Fast-tracking combination_prevention.pdf

12. Národní program řešení problematiky HIV/AIDS v České republice na období 2013-2017. [National programme for tackling HIV/AIDS in the period from 2013 to 2017]. Prague: Ministry of Health of the Czech Republic; 2013. Czech. Available from: https://www.mzcr.cz/obsah/narodni-programreseni-problematiky-hiv/aids_1688_5.html

13. Metodika pro žadatele o poskytnutní státní dotace v rámci Národního programu řešení problematiky HIV/AIDS pro rok 2016. [Guidelines for the applicants for government grants under the National Programme for tackling HIV/AIDS in 2016]. Prague: Ministry of Health of the Czech Republic; 2015. Czech. Available from: http://www.mzcr.cz/obsah/metodika_3333_1. html

14. Mravčík V, Chomynová P, Grohmannová K, Janíková B, Tion Leštinová Z, Rous Z, et al. Výroční zpráva o stavu ve věcech drog v Ceské republice v roce 2015. [Annual report on drug situation in the Czech Republic in 2015]. Prague: Office of the Government of the Czech Republic; 2016. Czech. Available from: https://www.drogy-info.cz/publikace/vyrocni-zpravy/ vyrocni-zprava-o-stavu-ve-vecech-drog-v-ceske-republice-vroce-2015/

15. Ministry of Health of the Czech Republic. Výsledky výběrového řízení dotačního programu MZ ČR Národní program řešení problematiky HIV/AIDS pro rok 2016. [Results of proceedings of the grant programme Ministry of Health of the Czech Republic the National programme for tackling HIV/AIDS in 2016]. Prague: Ministry of Health of the Czech Republic; 2015. Available from: http://www.mzcr.cz/dokumenty/vysledky-vyberovehorizeni-dotacniho-programu-mz-cr-narodni-program-reseniprobl_11183_3437_1.html

16. Hlavní hygienik ČR. Dopady restrikce v hygienické službě v letech 2006-2012 na zajištění ochrany a podpory veřejného zdraví a primární prevence nemocí v ČR. [Consequences of restriction of public health service in 2006-2012]. Prague: Ministry of health of the Czech Republic; 2014. Czech. Available from: http://docplayer. cz/17299183-Dopady-restrikce-v-hygienicke-sluzbe-v-letech2006-2012-na-zajisteni-ochrany-a-podpory-verejneho-zdravi-aprimarni-prevence-nemoci-v-cr.htm

17. European AIDS Clinical Society (EACS). Guidelines, Version 8.1, October 2016. Copenhagen: EACS; 2016. Available from: http:// www.eacsociety.org/files/guidelines_8.1-english.pdf

18. Spinner CD, Boesecke C, Zink A, Jessen H, Stellbrink HJ, Rockstroh JK, et al. HIV pre-exposure prophylaxis (PrEP): a review of current knowledge of oral systemic HIV PrEP in humans. Infection. 2016;44(2):151-8. https://doi.org/10.1007/ S15010-015-0850-2 PMID: 26471511

19. European Centre for Disease Prevention and Control (ECDC). Evidence brief: Pre-exposure prophylaxis for HIV prevention in Europe. Stockholm: ECDC; 2016. Available from: https:// ecdc.europa.eu/sites/portal/files/media/en/publications/ Publications/pre-exposure-prophylaxis-hiv-prevention-europe. pdf

20. Scott HM, Klausner JD. Sexually transmitted infections and pre-exposure prophylaxis: challenges and opportunities among men who have sex with men in the US. AIDS Res Ther. 2016;13(1):5. https://doi.org/10.1186/s12981-016-0089-8 PMID: 26793265
21. van Tienen C, van de Vijver D, Noori T, Sönnerborg A, Boucher C. Letter to the editor: Pre-exposure prophylaxis for HIV in Europe: The need for resistance surveillance. Euro Surveill. 2017;22(11):30483. https://doi.org/10.2807/1560-7917. ES.2017.22.11.30483

22. Snopková S, Rozsypal H, Aster V, Sedláček D, Kapla J, Jerhotová Z, et al. [Guidelines for caring for HIV-infected adults and post-exposure prophylaxis of HIV infection]. Klin Mikrobiol Infekc Lek. 2016;22(1):20-38. Czech. PMID: 27476591

23. Rozsypal H, Staňková M, Sedláček D, Snopková S, Kapla J, Aster V, et al. [Guidelines for caring for HIV-infected adults and postexposure prophylaxis for HIV infection]. Klin Mikrobiol Infekc Lek. 2013;19(2):62-71. Czech. PMID: 23991476

24. Hatzenbuehler ML, Link BG. Introduction to the special issue on structural stigma and health. Soc Sci Med. 2014;103(103):16. https://doi.org/10.1016/j.socscimed.2013.12.017 PMID: 24445152

25. Pitoňák M. Mental health in non-heterosexuals: Minority stress theory and related explanation frameworks review. Ment Health Prev. 2016. https://doi.org/10.1016/j.mhp.2016.10.002

26. Smit PJ, Brady M, Carter M, Fernandes R, Lamore L, Meulbroek $M$, et al. HIV-related stigma within communities of gay men: a literature review. AIDS Care. 2012;24(4):405-12. PMID: 22117138

27. Pitoňák M, Spilková J. Homophobic prejudice in Czech youth: a sociodemographic analysis of young people's opinions on homosexuality. J. Sex Res Soc Policy. 2016;13(3):215-29. https://doi.org/10.1007/s13178-015-0215-8

28. Kvášová S, Nečas V. HIV/AIDS v českých denících v proměnách času. [HIV/AIDS in the Czech Media (1996-2009)]. Adiktologie.2011;11(4):200-6. Czech. Available from: http://casopis.adiktologie.cz/public.magazine/downloadfile/215? name=2011_4_Kvasova_HIV-AIDS.pdf

29. HIV Justice Network/European AIDS Treatment Group (EATG). Stop the Prague public health authority's persecution and intimidation of people living with HIV. Brussels: EATG; 2016. Available from: http://www.hivjustice.net/news/stop-theprague-public-health-authoritys-persecution-and-intimidationof-people-living-with-hiv-press-release/

30. Aktuálně.cz. HIV pozitivní muži se vědomě nechránili, trestný čin ale podle policie nespáchali [HIV-positive men were not protecting themselves consciously, however they did not commit a crime according to police]. Prague: aktuálně.cz; 16 Nov 2016. Czech. Available from: https://zpravy.aktualne. cz/domaci/hiv-pozitivni-homosexualove-kteri-se-vedomenechranili-nespa/r 7298c214ac0211e687f7002590ofea04/?red irected $=1482910277$

31. Mears A. The criminalization of HIV transmission in England and Wales: a brief review of the issues arising. Curr Opin Infect Dis. 2007;20(1):47-53. https://doi.org/10.1097/ QC0.obo13e328013dab5 PMID: 17197881

32. Joint United Nations Programme on HIV/AIDS (UNAIDS). Ending overly broad criminalization of HIV non-disclosure, exposure and transmission: Critical scientific, medical and legal considerations. Geneva: UNAIDS; 2013. Available from: http:// www.unaids.org/sites/default/files/media_asset/20130530_ Guidance_Ending_Criminalisation_o.pdf

33. Dodds C, Keogh P. Criminal prosecutions for HIV transmission: people living with HIV respond. Int J STD AIDS. 2006;17(5):3158. https://doi.org/10.1258/095646206776790114 PMID: 16643681

34. Dodds C, Bourne A, Weait M. Responses to criminal prosecutions for HIV transmission among gay men with HIV in England and Wales. Reprod Health Matters. 2009;17(34):13545. https://doi.org/10.1016/Sog68-8080(09)34475-4 PMID: 19962647

35. Wolfová P. (People are not afraid of AIDS anymore). Lidé přestali mít strach z AIDS. Týden.2017;34/2017:84-6. Czech. Available from: https://www.slideshare.net/Bulovka/ lid-pestali-mt-strach-z-aids

\section{License and copyright}

This is an open-access article distributed under the terms of the Creative Commons Attribution (CC BY 4.0) Licence. You may share and adapt the material, but must give appropriate credit to the source, provide a link to the licence, and indicate if changes were made.

This article is copyright of the authors, 2017. 